Reducing project related uncertainty in the "fuzzy front end" of innovation - A comparison of German and Japanese product innovation projects

Prof. Dr. Cornelius Herstatt Dipl.-Ing. Birgit Verworn Prof. Dr. Akio Nagahira

Januar 2003

Arbeitspapier Nr. 18 


\title{
Reducing project related uncertainty in the "fuzzy front end" of innovation - A comparison of German and Japanese product innovation projects
}

\section{Cornelius Herstatt, Birgit Verworn and}

Institute of Technology and Innovation Management, Technical University of Hamburg-Harburg (Germany) and

\author{
Akio Nagahira, \\ Graduate School of Engineering, Tohoku University, Sendai (Japan)
}

\begin{abstract}
In this paper, we are going to report on the results of an exploratory piece of research about the typical front-end-related activities in 28 innovation projects carried out by 14 German and 13 Japanese companies to reduce project uncertainty. In all cases we observed a range of activities to reduce project specific risks and revealed differences in the practice of innovation management in both the German and Japanese companies. We interviewed managers of 13 Japanese and 14 German enterprises concerning 14 Japanese and 14 German New Product Development projects. The focus of our research was the so called "fuzzy front end", activities and typical deliverables in the innovation process which might be affected by front end management practice.
\end{abstract}

Overall, in the case of the German as well as the Japanese projects, the uncertainties affected by the market or technology could successfully be reduced during the "fuzzy front end" and the majority of projects achieved their objectives and efficiency targets. Nevertheless, our study revealed differences in the way such uncertainties were reduced by the companies in Japan and Germany. Generally speaking, the 14 Japanese projects relied on a thorough planning, delegation of front end activities and strict controlling mechanisms to minimize deviations from front end specifications later in the innovation process and hence, achieved efficiency. In contrast, in the majority of the 14 German projects we could neither observe such a formal planning nor such an intensive controlling procedure supported by methods and tools as in the case of the Japanese projects. Instead, the companies in our German sample integrated relevant functions like $R \& D$, marketing, sales, production or customer service from the beginning of the innovation process, usually already during the idea generation phase, to ensure that all critical information and perspectives were taken into consideration right from the beginning, to reduce uncertainties and later deviations as well as enhancing efficiency. Responsibilities were assigned during the fuzzy front end and rarely changed during the implementation of the project.

Keywords: Fuzzy front end; innovation risk, uncertainty; idea generation; project selection; project planning; Japan; Germany.

Biographical notes: Prof. Dr. Cornelius Herstatt is Director of the Institute for Technology and Innovation Management at the Technical University of HamburgHarburg, Germany. He received his MBA and Ph.D. degree at the University of Zurich, Switzerland. He has 7 years of industry experience and 7 years experience in management consulting. He specializes in the management of the innovation process, user innovation communities and lead user management. 
Birgit Verworn is a $\mathrm{PhD}$ student at the Institute for Technology and Innovation Management at the Technical University of Hamburg-Harburg. She received an MSc in process engineering from the Technical University of Hanover, Germany. She has two years of industry experience as a process engineer for Procter \& Gamble. Her thesis focuses on the "fuzzy front end" of innovation.

Prof. Dr. Akio Nagahira is a professor for entrepreneurship and management at the Institute for Management of Science and Technology (MOST) at Tohoku University in Sendai, Japan. He obtained his LL.B in Law and Ph.D. in Economics at the Tohoku University. Before his appointment to become a professor at Tohoku University, he had worked for the Development Bank of Japan, founded by the Japanese Government, as director of investments in new ventures and start-ups.

\section{Introduction}

\subsection{The fuzzy front end}

Recently, researchers and practitioners in the field of innovation management are paying more attention to the so called "fuzzy front end" of product development, also known as the "pre-development" phase [1], "pre-project activities" [2], or "pre-phase 0 " $[3,4]$. Managers have identified the front end as being the greatest weakness in product innovation [3, p. 103]. Why? Because it strongly determines which projects will be executed, and furthermore the quality, costs, and time frame are to a large extent defined here. But research in this field has clearly demonstrated that efforts to optimize the innovation process at this stage in practice are minimal. In contrast, effects on the overall efficiency and effectiveness of the whole innovation process are significant [5, p. 100]. Consistent with these findings, an extensive empirical study by Cooper and Kleinschmidt showed that "the greatest differences between winners and losers were found in the quality of execution of pre-development activities" [1, p. 26]. Two factors were identified as playing a major role in product success: the quality of executing the pre-development activities, and a well defined product and project prior to the development phase [6, p. 27].

A study of 788 new product launches in Japan confirmed that Japanese new product professionals view the importance of pre-development proficiency in much the same way as their American and European counterparts [7, pp. 422, 433].

In general, the front end ranges from the generation of an idea to either its approval for development or its termination [8]. Figure 1 shows a simplified figure of the product development process to demonstrate the stage in which the fuzzy front end plays a role in the innovation process. The product development process starts with an idea originating from basic research, customer based techniques, and creativity techniques [6, p. 45]. During phase I, the idea is evaluated. This could be an iterative process, where the idea is worked out in more detail and assessed in several steps. For instance, an initial rough assessment could be made according to "must meet" and "should meet" criteria such as strategic alignment, feasibility or company policy 'fit'. Following a more detailed investigation, it is typical for a quick and inexpensive assessment of the project in terms of market, technology, and financials to take place. Phase II tasks are the development of a more detailed product concept and the initial project planning. Output of the fuzzy front end is a detailed business plan which is the 
basis for the decision on a business case. The "later phases" commence with phase III, which is where the actual development of the product starts.

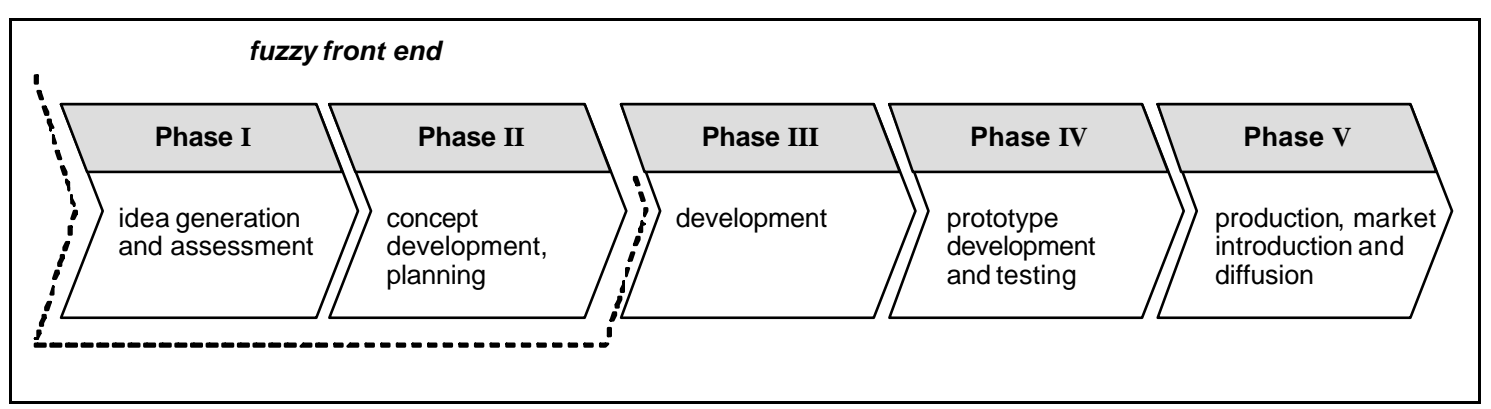

Figure 1: The product development process

\subsection{Reducing uncertainty in the front end of innovation}

Product development and the processes behind it can be seen as a series of activities related to problem solving. The more radical the product or process innovation, the more complex and iterative the problem solving process or the innovation process behind it. Typical risks jeopardizing the success of innovation for example, include inaccurate estimates of the future market demand, failing to develop the technology as planned or in extreme cases, a combination of both.

In the product development process relevant information has to be gathered in order to reduce such risks and uncertainties [9, pp. 252-254, 10, p. 228]. Uncertainty is defined as "the difference between the amount of information required to perform a particular task, and the amount of information already possessed by the organization" $[11$, p. 5]. The more that a risk or uncertainty can be reduced during the front end of this process, the lower the deviations from front end specifications, during the following project execution phases and hence, the higher the product development success.

Uncertainties inherent in New Product Development projects relate to the market and technology (see figure 2). The amount of information required very much depends on the type of New Product Development Project. Why? The highest level of newness to a firm is implied in the term radical innovation with an uncertainty in terms of both the market and the technology (upper right quadrant of figure 2). In contrast, incremental innovations like small product improvements tend to rely on existing internal information. Market and technical innovation can revert to existing knowledge in one dimension, whilst the other dimension is highly uncertain. Examples of this are the penetration of new markets with existing products, or the replacement of an obsolete technology inherent in a product without changing product features or the target market. 


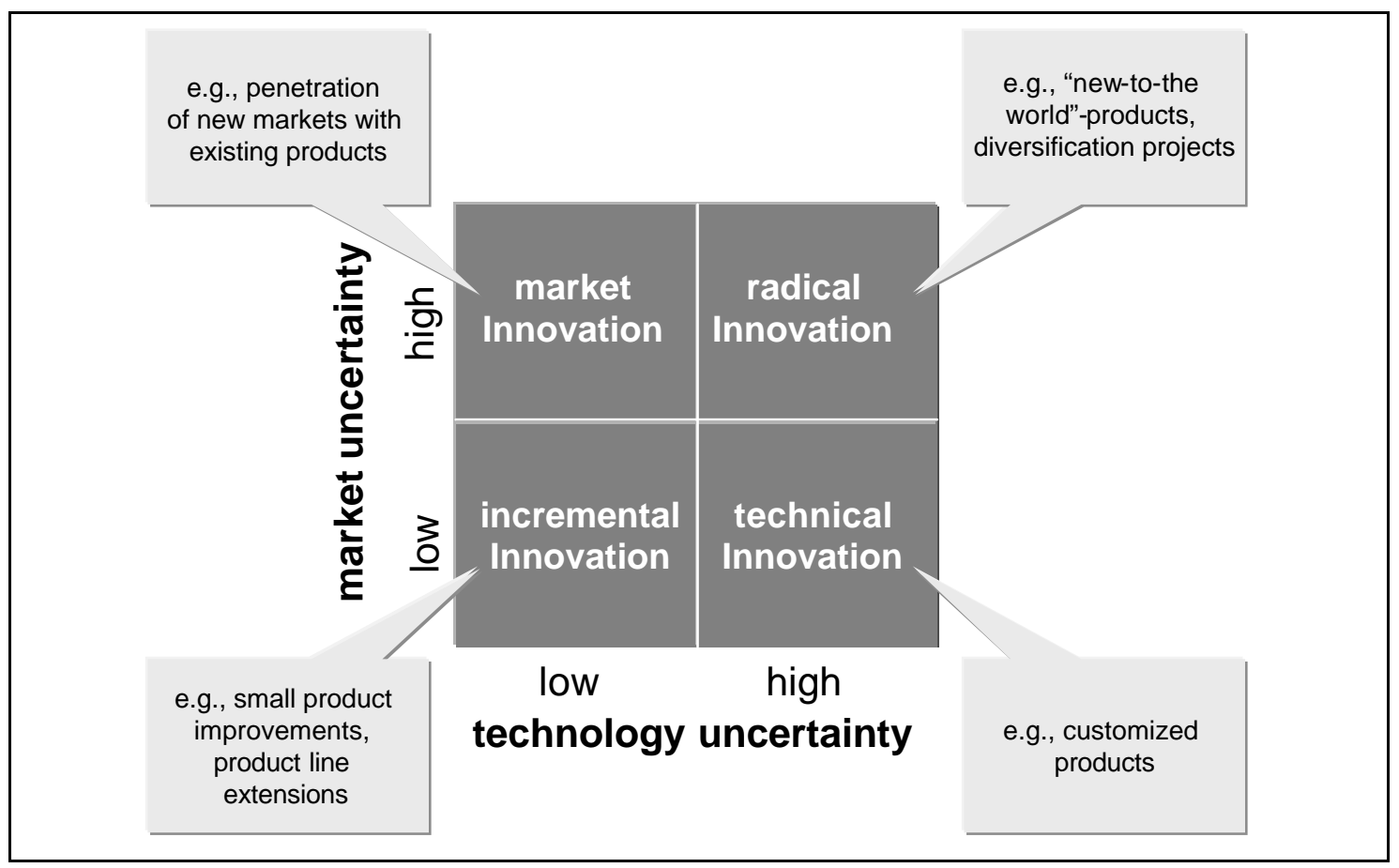

Figure 2: Uncertainty matrix [source: 12, p. 13, modified by the authors]

Therefore, the degree of newness of a New Product Development project to a firm is an important contextual factor, which influences how uncertainties are reduced during the product development process $[13$, p. 285,14 , pp. $536-539,15$, p. 132,9 , p. 253 , 16 , p. 304, 17, p. 318]. If information is not yet available and has to be sought from secondary sources, a different approach is needed to acquire this information. For example, when the newness of the market and technology to the firm are high, identifying customer needs and translating them into a product's technical specifications are much more challenging, and these activities will require completely different marketing and technical capabilities than would be needed if the newness to the firm is low [18, p. 73].

\subsection{Cultural differences}

In addition to the firm's perceived degree of newness of the planned product innovation, other factors such as branch specific or cultural differences might have an impact on the new product development process and particularly on the way uncertainties are reduced during the fuzzy front end phase.

Although often criticized, findings from Hofstede and others indicate a difference between cultures with regard to uncertainty avoidance $[18,19]$. Uncertainty avoidance according to Hofstede, measures the extent to which individuals are able to tolerate ambiguity [19, p. 112]. Whilst Galbraith takes an information processing view, Hofstede emphasizes subjective attitudes towards situations where little information is available. Both views can be combined to form the view that the basic information gathering tasks required for successful innovation differ in emphasis according to the level of perceived uncertainty [18, p. 65]. According to Hofstede, in Japan, uncertainty avoidance tendencies can be expected to be higher than in Germany [19, p. 122]. Consequently, in Japanese projects, a greater need to avoid ambiguity can be expected. In terms of New Product Development, this suggests that Japanese 
managers may tend to have a bias towards planning to reduce the possibility of failures [18, p. 64]. Furthermore, Japanese managers tend to define roles and responsibilities clearly, they also apply standardized procedures and draw upon a variety of tools and methods in innovation projects of high uncertainty [19, p. 264].

\section{Study}

\subsection{Aim of the exploratory study}

Most of large scale empirical studies of the fuzzy front end, as well as large scale cross-national comparative studies form part of the research on success factors for New Product Development, where most of the activities during the fuzzy front end were combined under one heading like "pre-development activities" [1, p. 26, 7, p. 433,20, p. 3] but not outlined in any further detail. This exploratory study tries to develop a deeper understanding of the major tasks to be undertaken during the fuzzy front end - to reduce project uncertainties, e. g. related to market or technology. In addition, former studies indicate that besides company or project specific contextual factors like company size or degree of newness of a project, cultural differences might influence innovation related activities including the front end [21, pp. 2-4, 14, p. 530, 7 , p. 432, 22, p. 5, 23, p. 222]. Therefore, the second objective of our exploratory study was to determine initial indicators of cultural differences in terms of the way that uncertainties are reduced at the start the innovation process. Germany and Japan were chosen because literature indicates differences in innovation management practices, particularly with regard to uncertainty avoidance [18, 19, 21, 24].

The aim and methodology of our study and a description of the samples are presented in the following section. The third section summarizes findings of our study. In chapter four, we formulate initial propositions, highlight managerial implications and make suggestions for future research.

\subsection{Methodology}

To reduce the complexity of our study, we focus on companies that are in similar industrial sectors and assume consistency in terms of sector related contextual factors. In Germany, we identified a total of 102 mechanical and electrical engineering companies located in the state of Hamburg by using the Hoppenstedt database [25]. All of these companies were contacted by telephone. Seven mechanical engineering companies and seven electrical engineering companies agreed to participate in our study. Finally, 14 in-depth interviews were conducted with the managers responsible for the development of new products during 2001.

In Japan, MOST (Management of Science and Technology Department) at the Tohoku University in Sendai contacted 28 mechanical and electrical engineering companies. 13 companies agreed to participate. In one large electrical engineering company, two projects were analyzed. In sum, 14 in-depth interviews were conducted in 2002 with three mechanical and nine electrical engineering companies. For pragmatic reasons, given that it was difficult to convince Japanese companies to participate in research from outside Japan, the sampling procedure in Japan differed from the procedure in Germany. Hence, although the Japanese companies in our 
sample operate in the same industry as the German companies and hence, products and markets are comparable, differences in our sampling methodology somewhat limited the impact of our comparative results.

Interviews lasted between two and three hours and were conducted by two interviewers in each country. The majority of the interviewees were directors of the Research and Development department (R\&D) or general managers. In six companies, both, the R\&D Director and Marketing Director were interviewed. In one of the Japanese companies, we were given the opportunity to interview the whole of the product development team. Interviews consisted of two parts: Firstly, interviewees were asked to briefly describe the development process and the outcome of the last product they had launched (last incident method) with the focus being on front end activities. The second part of the interview was solely based on a standardized questionnaire which was translated from German into Japanese for the interviews in Japan. The majority of the items were measured on a 7-point Likert scale. This two stage approach was designed to guarantee comparability of different interviews and to ensure that all of the issues perceived as being important by the interviewees could be addressed via the standardized questions.

\subsection{Sample}

A short description of all projects and respective companies is presented in the appendix to this paper.

\section{Company size:}

The German sample contains three large companies with 11,000, 200,000, and 420,000 employees respectively and annual sales of over one billion Euros. However, the majority of the German sample consists of small and medium sized enterprises (SMEs) with 25 to 360 employees and annual sales between 2 and 77 million Euros.

The Japanese sample is split equally between large companies with 2,500 to 10,000 employees and annual sales mostly over one billion Euro and SMEs with 66 to 930 employees and annual sales from 7 to 708 million Euros. On average, the Japanese companies are larger than the German companies. Therefore, one must consider that in the following analysis, differences in innovation management could, in addition to cross-national differences, be attributed in part to company size.

Project scope:

The average development time for new products developed was 20 months in Germany and 24 months in Japan.

Degree of newness:

Interviewees in both countries classified the newness of their product concepts and assessed the overall degree of newness of the product concept to their company (see figure 3 ). 


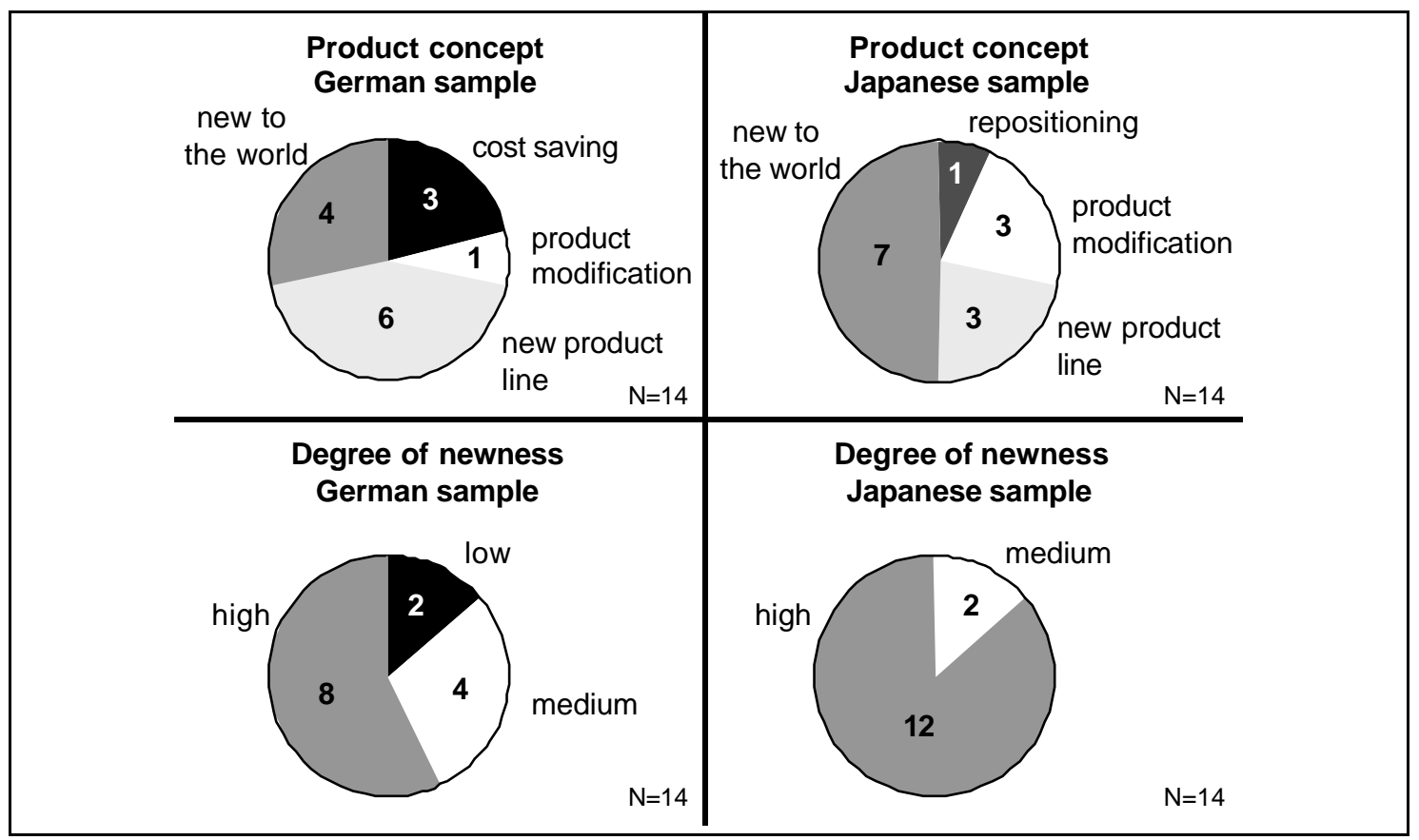

Figure 3: Degree of newness

Firstly, ten of 14 projects were classified as new product lines in Germany as well as in Japan. Secondly, regardless of whether using the classification of the product concept or the subjective overall rating, the newness of the Japanese product development projects got higher ratings of newness than German projects did. Thirdly, in both countries, the overall subjective assessment of the degree of newness to the company did not correspond to the (rather objective) classification of categories used in our questionnaire. For example, two cost saving projects were rated as highly new to the company. We came to the conclusion that there seems to be a general tendency to overestimate the degree of newness in an overall assessment of innovations. This conclusion is mirrored to a large extent by a recent German large scale study by Schlaak, in which 117 product development projects, of which the assessment of the overall degree of newness lead to high and homogeneous values, whereas a multi-dimensional measurement lead to lower and more differentiated values [16, p. 210].

Interviewees were asked to describe, which were the major areas of uncertainty in the product development projects in more detail. As already indicated by the degree of newness of the product concept (see figure 3), overall, uncertainties were perceived as higher in the Japanese projects. For the Japanese as well as the German projects, technology was the major source of uncertainty, but only on an average level in the German projects. In several of the German projects, there was a need to build new production lines, which was a further source of technological uncertainty. Corresponding to the fact that half of the Japanese projects were classified as new to the world (see figure 3), the target market and customers for the new products differed from markets already served by the Japanese companies. Regarding the German projects, most of the new products were introduced to existing markets.

To summarize, the need to reduce uncertainties was lower for the German projects and was mostly restricted to technology. For more than half of the Japanese projects, a high technological uncertainty was accompanied by a high market uncertainty. 
Project success:

Although we asked interviewees to describe the development of the last product introduced to the market, regardless of whether it was a success or failure, most of the projects in our sample were indeed successful. To assess the effectiveness of the projects, interviewees were asked, if objectives existed and if yes, were they achieved? (see figure 4). The five objectives we interviewed them about were relevant to the majority of the German projects (between 12 and 14) and all of the Japanese projects.

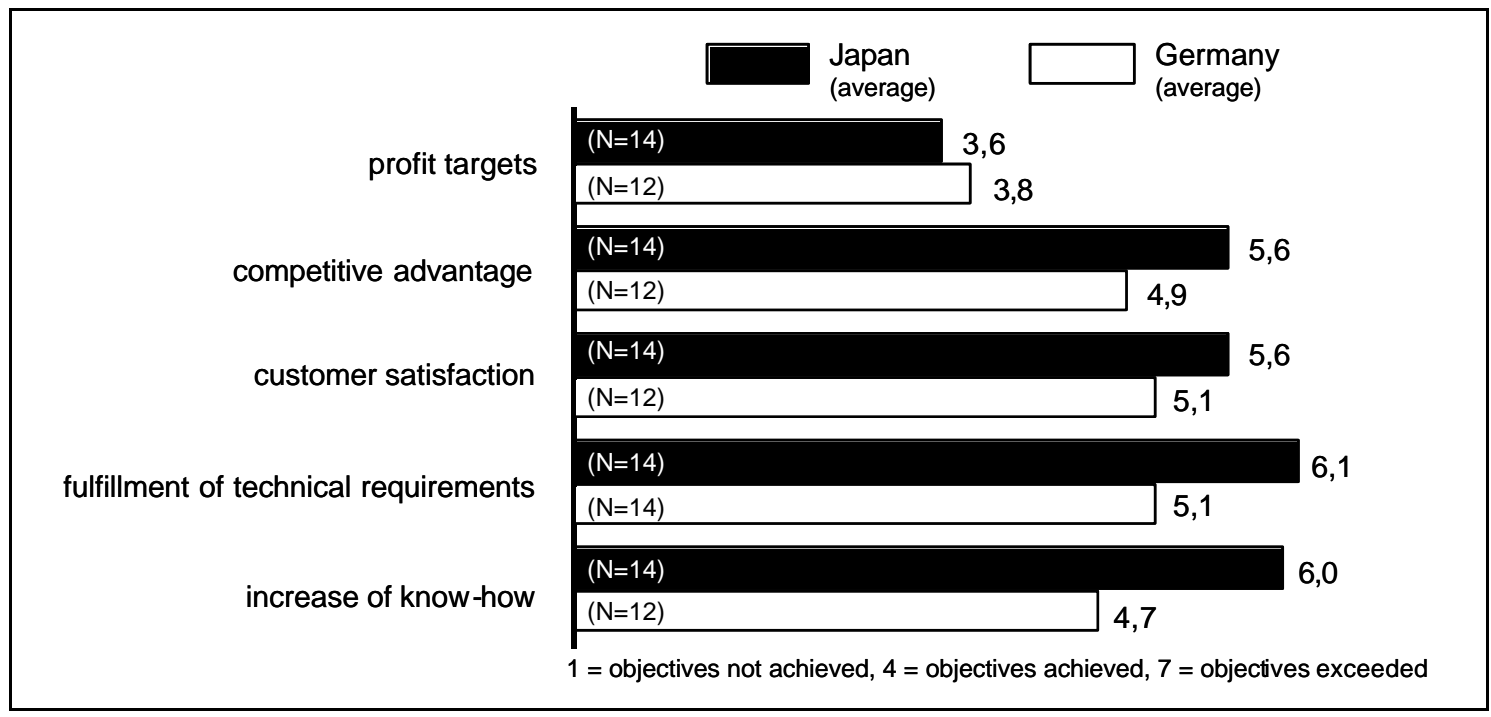

Figure 4: Achievement of objectives

Overall, the effectiveness of the projects was fairly high regarding competitive advantage, customer satisfaction, fulfillment of technical requirements, and increased know-how. For these objectives, all Japanese and German projects either met or exceeded their targets. Deficiencies were only observed in terms of finance, where target profits were not reached in two of the German and six of the Japanese projects. In sum, all of the Japanese and German interviewees were satisfied with the outcome of the projects. Therefore, regardless of the way uncertainties were reduced, the respective approaches which are about to be outlined in the chapters that follow, were successful.

\section{Results}

This section summarizes our key findings about the fuzzy front end and tries to identify initial indicators for country specific differences. Firstly, we will describe how ideas were generated, assessed, and selected. Secondly, we will summarize to what extent market and technological uncertainty were reduced prior to project execution. Finally, we will describe the intensity of project planning activities as a further opportunity to reduce project related uncertainties and as a basis of controlling during the following steps of the product development process.

As already mentioned in the previous section, the findings of our research are affected by several limitations, e.g., different sampling procedures in Germany and Japan and a small sample size of 14 projects in each country. Therefore, we will only interpret 
differences between Japanese and German projects, but if having completed the interviews we are under the strong impression that a difference exists which can be explained, and the difference between average values is relatively high to confirm our impression, these will be included.

\subsection{Idea generation}

The idea generation process is a combination of an organizational need, problem, or opportunity with the purpose of satisfying this need, solving a problem, or capitalizing on an opportunity. Although, the generation of ideas is often a complex and creative task, some researchers recommend reducing this uncertainty by assigning the tasks of systematic gathering, storing, and transferring all idea related information to specific individuals.

But since a greater number of ideas can often be more efficiently and systematically created by teams or groups, it is often recommended that systematic procedures like creativity techniques [see 25 for an overview of creativity techniques] and team based techniques (like brainstorming) should be applied. On the other hand, some authors claim that individual idea generation produces more creative solutions than those from groups [27, p. 289]. However, most authors favor an interdisciplinary group for idea generation [28, p. 40, 26, pp. 284, 294-296, 29, p. 656, 27, p. 289, 20, p. 9]. $\mathrm{R} \& \mathrm{D}$ and marketing as well as other functions (e.g., production, customer service) should cooperate early on in this creative process. Such a multidisciplinary integration ensures that customer needs and technological capabilities are taken into sufficient consideration, even in the early stages of the innovation process $[29$, p. 656]. A joint understanding and shared goals concerning the innovation, early in the process will have a positive influence on the project or even foster the information transfer between departments and therefore reduce uncertainties.

A general and vital precondition for all of these activities is that employees (individuals and teams) have sufficient time at their disposal to either collect relevant information or search for new ideas in addition to performing their regular business activities [27, p. 291, 28, p. 41].

Our findings concerning idea generation in the context of companies in both countries are presented in figure 5. They indicate differences in the way German and Japanese companies manage the idea creation process for new products.

Whereas the 14 Japanese projects were supported more in terms of systematic procedures and tools (such as a systematic information management process or the use of creativity techniques), the 14 German projects are characterized by a stronger emphasis on interdisciplinary teams and scope for the employees to generate new ideas.

Whilst only three of the 14 ideas in Germany, which suffered from limited resources in small enterprises, were not generated by an interdisciplinary team, six of the Japanese ideas were generated by one solitary function. These six ideas occurred in medium or large enterprises so that restriction to one function cannot be made accountable for, due to limited resources. Furthermore, the Japanese companies clearly favored allocating responsibility to a single competent person within one function, whilst the German companies clearly preferred a team approach to 
generating ideas for product development. This finding was somewhat surprising, since we had expected an equally or perhaps an even more team oriented approach in the case of information processing in the Japanese sample. One interpretation of these findings is that the Japanese Companies in our research try to encourage individuals and teams of people from various functions to collect and process ideas.

Our present study corresponds with former findings about the rare use of tools and methods to support generation of new ideas in the Western culture [30, p. 13, 31, p. 114,32 , pp. 11-13] in contrast to the frequent use of brainstorming in Japan [33, p. 26]. In 11 out of 14 German projects, creativity techniques were not used at all, whereas in 12 of the Japanese projects, brainstorming was applied. (In contrast, a comparative study in the chemical industry showed that creativity techniques were more often used in Germany than in Japan. Corresponding to our study, brainstorming was the most commonly used creativity technique [24, p. 129].)

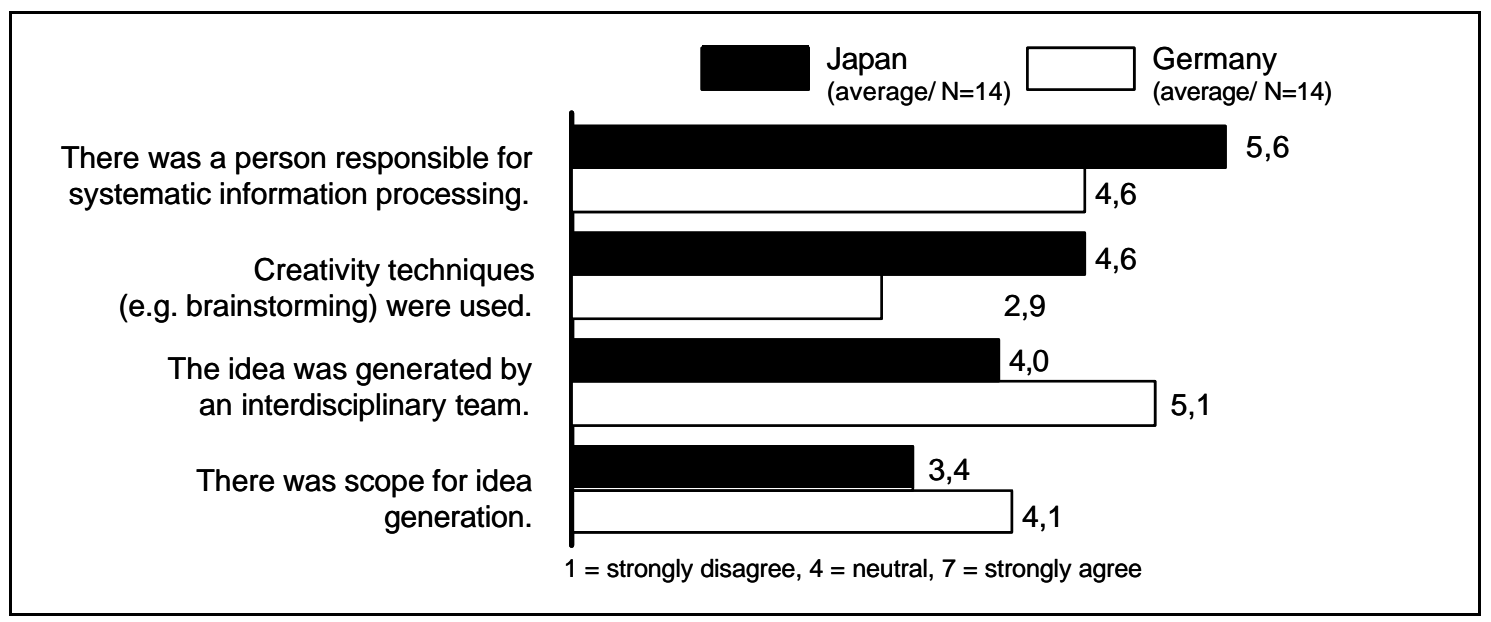

Figure 5: Idea generation

Overall, our research indicates differences in the way Japanese and German companies organize their idea generation processes. Whilst the Japanese managers assigned clear responsibilities to individuals as well as to teams and made use of systematic procedures including creativity techniques to reduce uncertainties early in the process, in the case of the German projects, ideas were generated by interdisciplinary teams, mostly not applying any specific procedures or such techniques. Instead these teams had been allocated sufficient time (scope) to develop ideas for innovation.

\subsection{Idea assessment}

Idea assessment is necessary to decide on the execution of an idea or to select the most promising idea from alternatives. The importance of this step within the product development process is empirically supported by studies in Western countries as well as in Japan and other countries [34, p. 82, 1, p. 25, 35, p. 119, 14, p. 540, 7, p. 431]. Given that decisions frequently have to be made without having all of the relevant information to hand, idea assessment is a necessary step in the innovation process, but it is accompanied by a high degree of uncertainty. The more radical the innovation project, the more difficult an early assessment of an idea becomes. 
As in the case of idea generation, some authors recommend taking an interdisciplinary approach to idea assessment to ensure that all facets and perspectives are taken into consideration and that uncertainties are reduced as far as is possible [36, pp. 154-156, 20, p. 9]. In this case, such a team has to develop a rich set of criteria in order to effectively evaluate the list of ideas created by individuals or teams. Such criteria typically address technical and/or economical aspects. Furthermore, some studies have identified a proficient financial analysis to be a major success factor for innovation [37, p. 42, 38, pp. 187-189, 14, p. 540]. But such an analysis needs a minimum level of concrete ideas, of course. Unfortunately such rich data is hardly ever available for breakthrough type innovations during the early phase of the innovation process, the "fuzzy front end".

The results of our research paint the following picture: Firstly, six of the 14 companies in Germany (five of the 14 companies in Japan) were in a position where the New Product Development project was already scheduled anyway. One of the companies, e.g., had to adapt to a technical change in the target market. These six (five) companies assessed the idea but did not have to select between alternatives. Hence, in the following analysis, only the remaining eight (nine) companies which had built in a project selection step into their product development process have been considered.

Regarding the interdisciplinary approach to idea assessment, as in the case for the German projects (see figure 6), the findings are slightly misleading. All three projects managed by one function are included in the sample of 14 projects for idea generation and eight projects for idea assessment. The decrease in mean values in figure 6 compared to figure 5 is therefore caused by having a smaller sample. In Germany, all ideas that were selected by an interdisciplinary team were already generated by multiple functions. In Japan, similar to our results with regard to idea generation, the level of multidisciplinarity for idea assessment was slightly lower than in Germany.

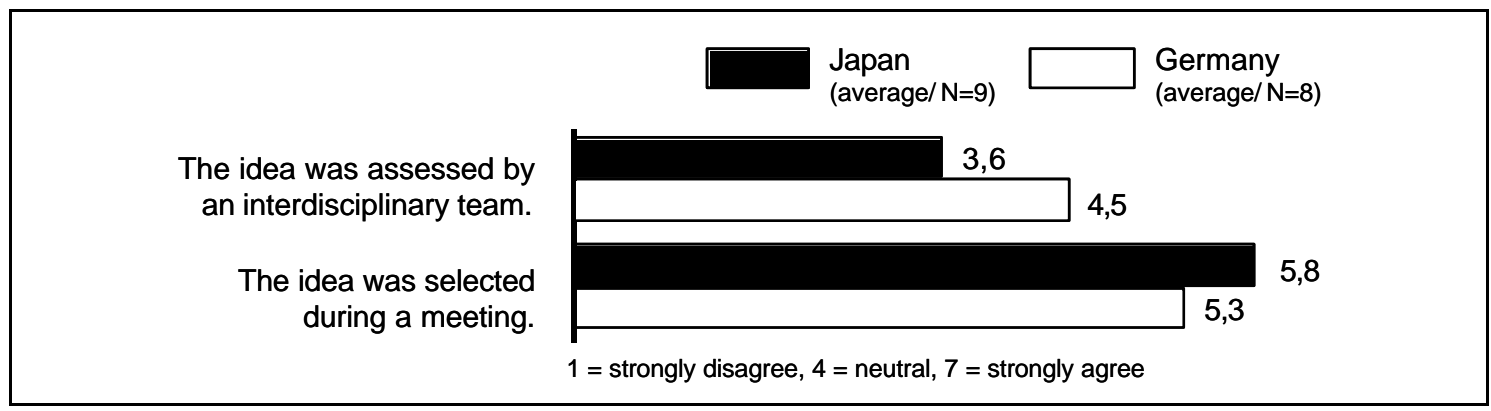

Figure 6: Idea assessment

In Germany, idea selection took place in meetings, where the various functions of the company were represented. Only one company held a meeting with participants from one department only. To the contrary, in Japan, five of the nine ideas were assessed during meetings with participants from one function only (like $R \& D$, production or marketing/sales). This early assessment included discussions concerning the technical as well as economical attractiveness of the projects. At first glance, it seems surprising that although the Japanese culture is supposed to be more collectivist than the German culture, in our study the German projects were characterized by a more interdisciplinary team approach during the fuzzy front end. However, reconsidering 
the results, as the Japanese projects had a medium to high degree of newness to the firms, involving people from different functions may offer the opportunity to integrate diverse information and perspectives, but will also lengthen the process substantially, due to the collectivist element to be expected in such meetings. This view is supported by recent research that suggests that Japanese managers are willing to spend a substantial amount of time achieving group consensus in a harmonious setting $[18, \mathrm{p}$. 66]. But in order to run such evaluation sessions effectively, it makes sense that in the 14 Japanese projects, various meetings were held during the fuzzy front end, but mostly between people in one function: Implementing this approach, enables them to achieve a much faster consensus of opinion on development issues.

Table 1 shows the importance of technical and economical criteria for the assessment of an idea in Germany and Japan. Most of the companies considered technical as well as economical criteria (16 of 17) and therefore tried to base their decisions on minimum technological and market/economical uncertainty.

\begin{tabular}{|l|l|c|c|c|c|}
\hline \multicolumn{2}{|c|}{ Germany } & \multicolumn{3}{|c|}{ technical criteria } \\
\cline { 2 - 6 } & $\begin{array}{c}\text { not } \\
\text { impor- } \\
\text { tant }\end{array}$ & $\begin{array}{c}\text { neu- } \\
\text { tral }\end{array}$ & $\begin{array}{c}\text { very } \\
\text { impor- } \\
\text { tant }\end{array}$ & sum \\
\hline \multirow{2}{*}{$\begin{array}{l}\text { econo- } \\
\text { mical } \\
\text { criteria }\end{array}$} & $\begin{array}{l}\text { not } \\
\text { impor- } \\
\text { tant }\end{array}$ & - & - & - & - \\
\cline { 2 - 6 } & neutral & - & - & 3 & 3 \\
\cline { 2 - 6 } & $\begin{array}{l}\text { very } \\
\text { impor- } \\
\text { tant }\end{array}$ & - & 2 & 3 & $\mathbf{5}$ \\
\cline { 2 - 6 } & sum & - & $\mathbf{2}$ & $\mathbf{6}$ & $\mathbf{8}$ \\
\hline
\end{tabular}

\begin{tabular}{|c|l|c|c|c|c|}
\hline \multirow{2}{*}{ Japan } & \multicolumn{3}{|c|}{ technical criteria } \\
\cline { 2 - 6 } & $\begin{array}{c}\text { not } \\
\text { impor- } \\
\text { tant }\end{array}$ & $\begin{array}{c}\text { neu- } \\
\text { tral }\end{array}$ & $\begin{array}{c}\text { very } \\
\text { impor- } \\
\text { tant }\end{array}$ & sum \\
\hline \multirow{2}{*}{$\begin{array}{l}\text { econo- } \\
\text { mical } \\
\text { criteria }\end{array}$} & $\begin{array}{l}\text { not } \\
\text { impor- } \\
\text { tant }\end{array}$ & - & - & 1 & $\mathbf{1}$ \\
\cline { 2 - 6 } & neutral & - & - & 1 & $\mathbf{1}$ \\
\cline { 2 - 6 } & $\begin{array}{l}\text { very } \\
\text { impor- } \\
\text { tant }\end{array}$ & - & - & 7 & $\mathbf{7}$ \\
\cline { 2 - 6 } & sum & - & - & $\mathbf{9}$ & $\mathbf{9}$ \\
\hline
\end{tabular}

Table 1: Importance of technical and economical selection criteria

Concerning the methodological support of idea assessment, in about half of the German as well as the Japanese projects, selection criteria used were weighted (see figure 7). An analysis of cost effectiveness seems standard for Japanese projects regardless of company size. In Germany, only one medium sized and two larger companies carried out an analysis of cost effectiveness. A comparative study in the chemical industry showed different results. Whilst the weighting of criteria was more common in Japan than in Germany, no significant differences were found with regard to cost effectiveness analysis [24, pp. 140-142]. Nevertheless, a stronger methodological support of idea assessment in Japan is a similarity that was also found in other studies from different industry sectors. 


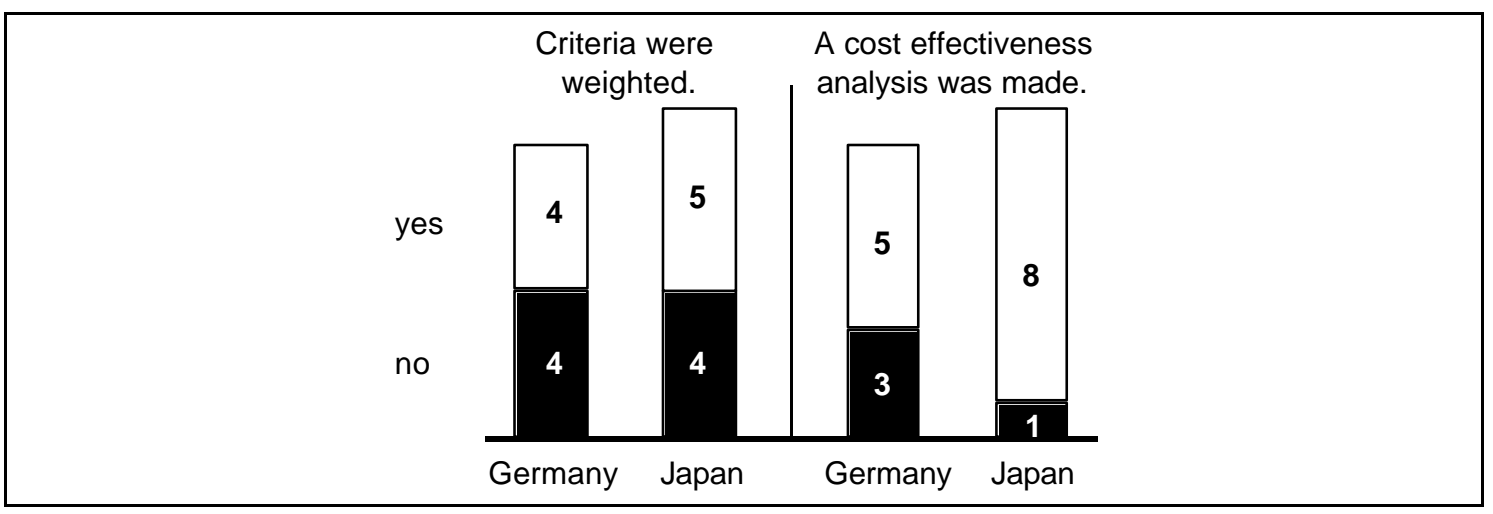

Figure 7: Methodological support of idea assessment

To summarize, whereas in the German projects, ideas were often assessed during meetings with participants representing various functions, in the case of the Japanese projects, meetings were held with participants from one function only. In both countries, idea assessment relied on technical and economic criteria which were weighted in about half of the cases. Whilst a cost effectiveness analysis seems standard in Japan, only a few larger enterprises in Germany elaborately calculated costs. Again, as for idea generation, in the Japanese projects the use of methods was emphasized whereas in the German projects interdisciplinary teams were used to reduce uncertainties during decision making.

\subsection{Reduction of market uncertainty prior to development}

After selecting an idea to be worked out in more detail, market uncertainty has to be reduced further, which should lead to a more in-depth understanding of the market. The target market has to be defined and customer requirements integrated into the product concept, prior to development [39, p. 274, 6, p. 26, 1, p. 26, 3, p. 113, 40, p. 198,7, p. 427]. For new markets, it is more difficult to reduce market uncertainty as potential customers are often unable to articulate their needs or may not even be aware of them [10, p. 228]. Therefore, we expected the challenge to be higher for the Japanese projects of our sample as they were characterized as "new to the world" products for at least half of the cases.

One possibility to reduce market uncertainty is to extensively use customer or user information for developing the new product concept. This type of information can either be gathered by direct contact with customers or by relying on functions operating closely with client organizations such as after sales/customer service.

The amount of information from these functions in our sample was similar in Japan and Germany, on average on a medium level (see figure 8). Direct contact to customers was more important for the initiation of German as well as Japanese projects of our study. 


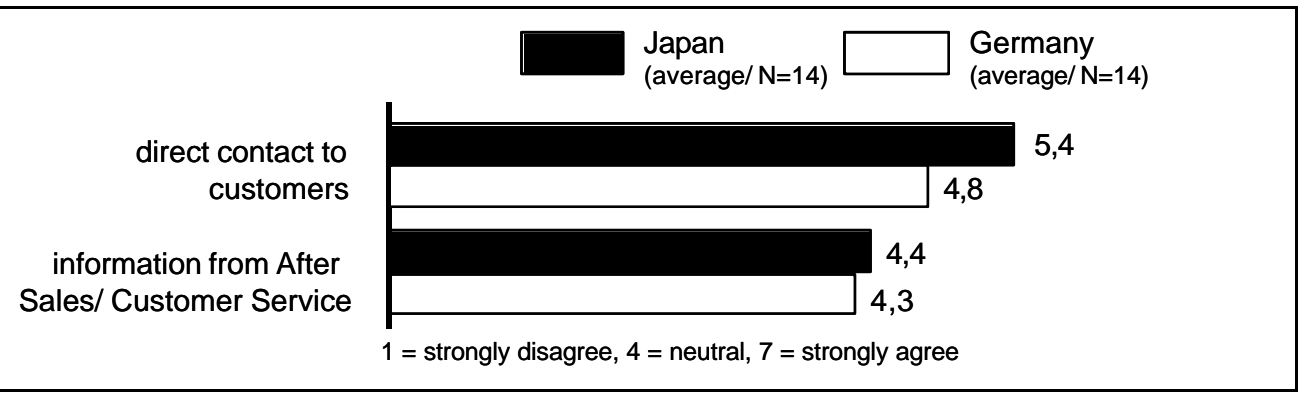

Figure 8: Initiation

Overall, our findings with regard to initiation resemble the results of a large scale cross-national comparison between Germany, Japan, and the United States [41, pp. 311-313].

Figure 9 reflects the results of our study with regard to the achieved market uncertainty reduction at the end of the "fuzzy front end". For the Japanese as well as for the German projects, the remaining market uncertainty prior to development was relatively low. The target market and customer needs were well understood before the proceeding with development. We are under the impression, that in the Japanese projects the customer requirements played a slightly more important role in defining the product compared to the German projects. This might be explained by the fact, that the Japanese new product concepts were partly targeted at new customers.

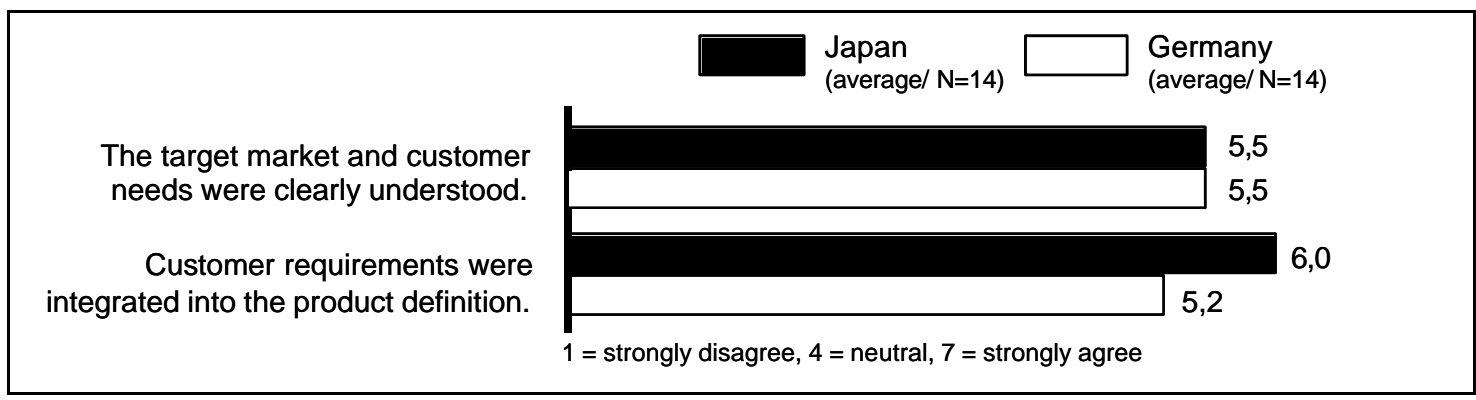

Figure 9: Reduction of market uncertainty prior to development

To summarize, reduction of market uncertainty prior to development was achieved in the majority of projects both in Japan and Germany.

\subsection{Reduction of technical uncertainty prior to development}

Besides reducing market uncertainty, reducing technological uncertainty is a further key task during the fuzzy front end. For both samples this was a major task, as the 28 projects were characterized by a medium to high degree of newness. This means that interviewees felt unable to predict or completely understand some aspects of the technological environment at the very beginning [18, p. 61]. For example, some interviewees perceived the product technology as under-developed and unknown and, thus, a trial and error research was considered unavoidable.

According to Moenaert et al., the amount of information acquired with regard to technology is a key differentiating factor between successful and unsuccessful projects. [9, p. 249]. The NewProd studies of Cooper and Kleinschmidt indicate a 
strong correlation between preliminary technical assessment and project outcomes [34, p. 82]. In Cooper and Kleinschmidt's measurement, preliminary technical assessment includes, among other things, a feasibility analysis and the definition of product specifications. In NewProd, preliminary technical assessment was undertaken in $85 \%$ of projects and was regarded as effectively undertaken. Song and Parry likewise report a highly significant correlation between technological information prior to development (measured with six items) and project success in Japan [7, p. 431].

Our results paint a similar picture. Technical uncertainty prior to development was relatively low for the German and Japanese projects (see figure 10). Technical requirements were not defined in two projects, and technical feasibility was not verified in one of fourteen German projects. In all of the Japanese projects requirements were defined and technical feasibility was checked at least to some extent.

To summarize, reduction of technical uncertainty prior to development was achieved in the majority of the projects studied with no indication for cultural differences.

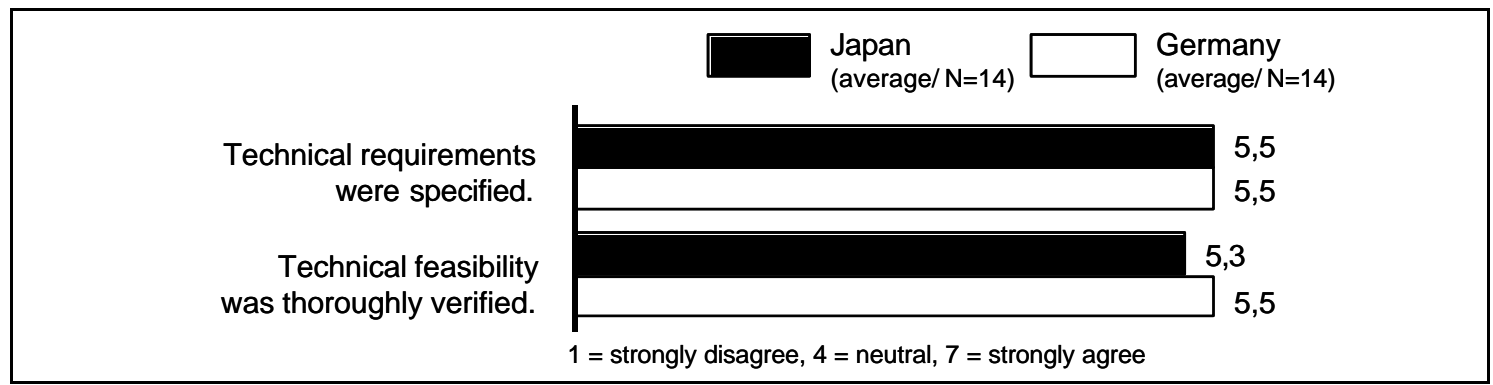

Figure 10: Reduction of technical uncertainty prior to development

\subsection{Front end project planning}

When the overall objective of a New Product Development project is clear, an initial planning before the start of the development of the new product translates the overall project goals into a series of activities and allocates resources to these activities. Although some information needed for the planning may at that point in time be difficult to forecast, overall uncertainties are reduced by laying out a rough process from development to product launch.

The first step of front end project planning is to break the product development project down into various work packages. Thereafter, timings, resources and overall responsibilities are allocated to the work packages. In addition, cost projections should be made and responsibilities should be assigned on an individual basis. The task of project planning can be supported by several tools and methods like bar charts, network plans, or project management software [42, p. 73]. Several large scale studies suggest that a proficient planning contributes significantly to the success of projects in Western countries [13, p. 279, 42, p. 67, 40, p. 198]. Song and Parry identified similar results for Japan [7, p. 432]. Khurana and Rosenthal's exploratory study of incremental innovation projects in the U.S., Europe, and Japan observed deficiencies such as confusion about priorities and incomplete resource planning, which led to 
delays and product strategy mismatches [3, p. 111]. Results from Hofstede and Song et al. suggest that the intensity of the planning activities during the Japanese projects can be attributed to a higher level of uncertainty avoidance than is common in Germany $[19,18]$.

In our study, project planning is a front end activity that reveals clear differences in the management of Japanese and German projects and supports our proposition based on the studies from Hofstede and Song et al. (see figure 11).

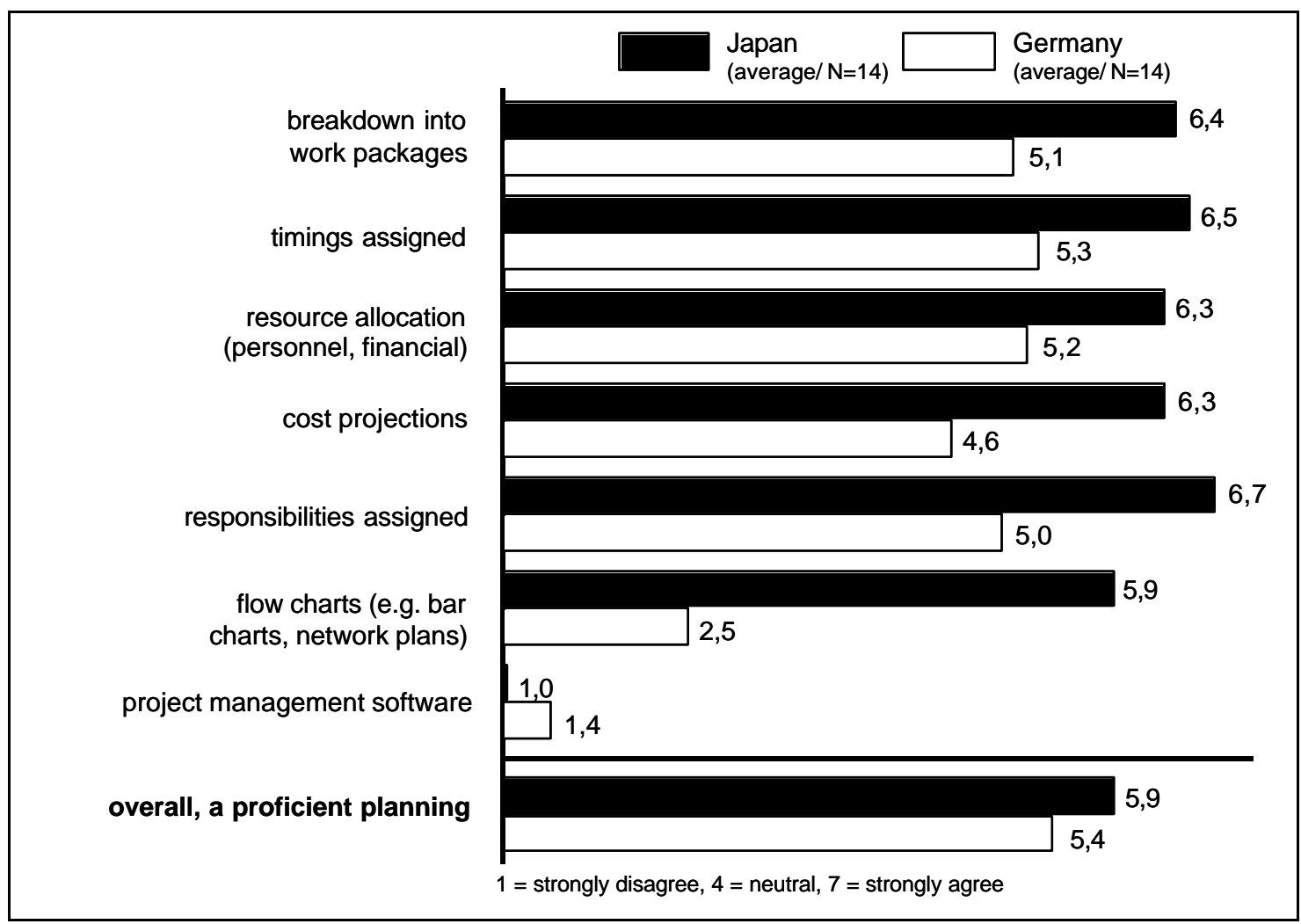

Figure 11: Front end project planning

In every aspect of project planning, average values were higher for the 14 Japanese projects. Two of the German projects did not even have a front end project planning step at all. As expected, this was the case for product development projects in small firms (25/140 employees) and esulted in low project efficiency. The three large enterprises in our German sample carried out detailed planning for every aspect. Nevertheless, differences between German and Japanese projects cannot be explained by company size. In Japan, smaller enterprises had the same front end planning standard than larger enterprises. This country specific difference is abundantly clear for cost projections and flow charts, which were routinely utilized in all of the Japanese projects but in contrast, were an exception in Germany. This is consistent with our findings about the routine use of cost effective analysis in the Japanese sample compared to the German sample. Similarities between Japanese and German projects had already indicated in previous research that there is rarely project management software support for front end planning [43, pp. 155-157]. In Germany, four companies used project management software, whereas, to our surprise, such software was not used at all in the Japanese companies, where in some cases they were completely unaware that such tools existed. 
Interviewees were asked to assess not only the assessment of individual steps of front end planning, but also the overall proficiency of their front end planning. The average value for the German sample was surprisingly high compared to the assessment of individual planning issues, as well as compared to the overall assessment of the Japanese projects. Obviously, many of the German interviewees did not attach much importance to front end planning, whilst it was a routine step in the new product development process for the Japanese projects.

Overall, in our study, the most predominant differences between our Japanese and German sample was due to the management of fuzzy front end planning. Whilst proficient planning, including cost projections and flow charts seems standard for Japanese projects, regardless of firm size, the proficiency of front end planning is lower and divergent between the projects studied in Germany.

Given that the front end planning research revealed such interesting insights, we have decided to present the results of our study regarding controlling too, despite it not being a front end task. However, as controlling is based on deliverables defined during the fuzzy front end, differences between Japanese and German management practice can be expected to be found during controlling in the later phases of the process. In addition, as for planning, differences in uncertainty avoidance tendencies suggest a stricter approach to controlling in Japan than in Germany.

One of the principle controlling tasks is to detect deviations from the plans as early as possible. Furthermore, reasons for deviations should be ascertained, the impact assessed and a corrective action plan developed [44, p. 216].

Consistent with our proposition and findings about project planning, the proficiency of controlling is significantly higher in our Japanese sample compared to our German sample (see figure 12). Regardless of company size, the Japanese firms allocated substantially more effort in drawing up plans and controlling them.

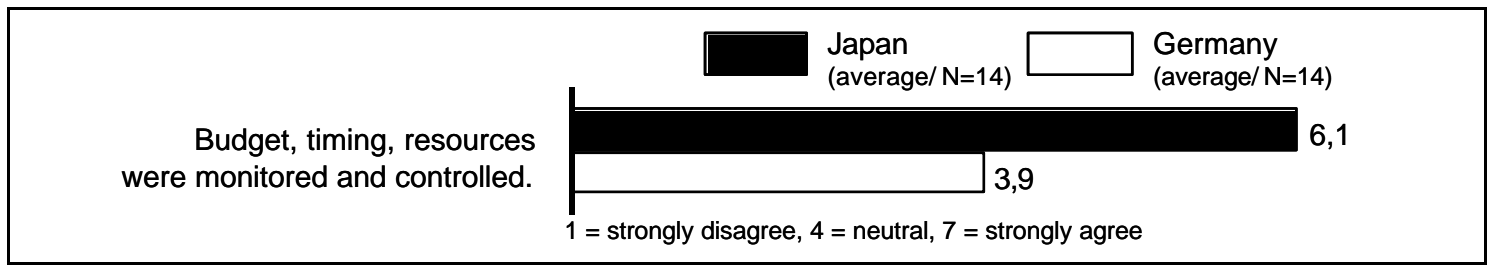

Figure 12: Controlling

To summarize, similar to idea generation and assessment, initial planning is a more routine practice in the 14 Japanese projects of our study. Some of the 14 German projects did not have a front end planning step at all and support by methods and tools was the exception, whilst the Japanese interviewees drew flow charts for example as a matter of routine.

\section{Conclusions}

Despite the sample size being small and different sampling methods being utilized in Germany and Japan, our study revealed some interesting results. Contrary to former studies, the fuzzy front end of 14 projects studied in Japan and 14 projects studied in Germany were predominantly managed proficiently. Market uncertainty and technical 
uncertainty could have been substantially reduced prior to development. The majority of objectives were achieved for all projects. Yet, with regard to uncertainty reduction, in agreement with former findings about uncertainty avoidance in both countries, a different approach was identified in the Japanese sample, compared to the German projects. Whilst Japanese projects relied on a thorough planning and a strict regime of control to minimize deviations from front end specifications and enhance efficiency, in our German projects, functions were integrated early in the innovation process, in some cases already during idea generation phase, to ensure that all information and perspectives were taken into consideration right from the start. Responsibilities were assigned during the front end and rarely changed during project implementation to reduce deviations and enhance efficiency.

In summary, we suggest the following propositions for the "fuzzy front end":

Proposition 1: In Japanese New Product Development projects, project related uncertainties are reduced via strong methodological support and in particular a more elaborated planning model compared to German New Product Development projects.

Proposition 2: The early integration of corporate functions into the fuzzy front end of innovation to reduce project related uncertainty is more typical for German compared to Japanese innovation management style.

Proposition 3: Monitoring and controlling of budgets, timing and resources during the whole innovation process (including the fuzzy front end) is systematically carried out in Japanese companies and more elaborated in contrast to German companies.

For the management of innovation practice, our results indicate that there is no such thing as the "best" approach to reduce market and technological uncertainty and to successfully manage the fuzzy front end of innovation. In general, a company can choose either a more formal or a more interdisciplinary, informal approach. This decision will depend, besides other influencing factors, on the culture of the enterprise. When deciding on the most appropriate approach for a given company, one of the key points of consideration should be employee attitudes towards uncertainty. If employees tend to be risk averse, formal procedures and a tight planning/control process might be more appropriate than a rather informal network approach.

But due to the limited sample size of our study and different sampling procedures, our findings cannot be generalized. Nevertheless, initial indicators for country specific approaches to managing the fuzzy front of innovation were found. These findings suggest a contingency approach: The influence of contextual factors on the fuzzy front end should be considered in more detail and the sample size should be extended to enable a more elaborated analysis. Furthermore, studies of the fuzzy front end could be extended to other countries and industries. In particular, a comparison between countries with a more pronounced difference in terms of uncertainty avoidance tendencies, e.g., Japan and the U.S., would be promising. Another fruitful research area would be to explore the impact of uncertainty avoidance tendencies on individual behavior in more detail. 
Appendix: List of projects

\begin{tabular}{|c|c|c|c|}
\hline No. & $\begin{array}{l}\text { Type of company and size } \\
\text { (number of employees) }\end{array}$ & Rough description of the project & $\begin{array}{l}\text { Newness of the } \\
\text { product concept to } \\
\text { the firm and } \\
\text { development time }\end{array}$ \\
\hline 1 & $\begin{array}{l}\text { Japanese manufacturer of } \\
\text { electronic components } \\
\text { (150 employees) }\end{array}$ & $\begin{array}{l}\text { Power resistor with temperature } \\
\text { characteristics based on metal foil } \\
\text { technology }\end{array}$ & $\begin{array}{l}\text { New to the world, } \\
12 \text { months }\end{array}$ \\
\hline 2 & $\begin{array}{l}\text { Japanese manufacturer of } \\
\text { electrical products } \\
\text { (600 employees) }\end{array}$ & $\begin{array}{l}\text { Pointing device for personal computers } \\
\text { ("mouse") for patients who suffer } \\
\text { from muscle dysfunctions }\end{array}$ & $\begin{array}{l}\text { New to the world, } \\
2 \text { months }\end{array}$ \\
\hline 3 & $\begin{array}{l}\text { Japanese manufacturer of } \\
\text { electronic components } \\
\text { (4000 employees) }\end{array}$ & $\begin{array}{l}\text { Three dimensional motion sensor, used } \\
\text { for example to protect PCs or mobile } \\
\text { phones from physical damages (e.g., } \\
\text { via deactivating the device in the case } \\
\text { of slipping from a table) }\end{array}$ & $\begin{array}{l}\text { New product line, } \\
12 \text { months }\end{array}$ \\
\hline 4 & $\begin{array}{l}\text { Japanese manufacturer of } \\
\text { transistors and IC products } \\
\text { (930 employees) }\end{array}$ & $\begin{array}{l}\text { Switching element for communication } \\
\text { products (e.g., telephones, mobile } \\
\text { phones); triggering device for pulse } \\
\text { ignitions }\end{array}$ & $\begin{array}{l}\text { New product line, } \\
4 \text { months }\end{array}$ \\
\hline 5 & $\begin{array}{l}\text { Japanese producer of } \\
\text { chemical products } \\
\text { ( } 2465 \text { employees) }\end{array}$ & $\begin{array}{l}\text { Polymer used in the production of } \\
\text { optical lenses or eye glasses }\end{array}$ & $\begin{array}{l}\text { New to the world, } \\
120 \text { months }\end{array}$ \\
\hline 6 & $\begin{array}{l}\text { Japanese manufacturer of } \\
\text { electronic components and } \\
\text { products } \\
(123 \text { employees })\end{array}$ & $\begin{array}{l}\text { Electronic device to purify water for } \\
\text { home and professional applications } \\
\text { (e.g., laboratories, medical doctors or } \\
\text { dentists) }\end{array}$ & $\begin{array}{l}\text { New to the world, } \\
10 \text { months }\end{array}$ \\
\hline 7 & $\begin{array}{l}\text { Japanese industrial } \\
\text { automation company } \\
\text { (6000 employees) }\end{array}$ & $\begin{array}{l}\text { Production in-process control system } \\
\text { with special characteristics (e.g., } \\
\text { constant imaging) }\end{array}$ & $\begin{array}{l}\text { New to the world, } \\
12 \text { months }\end{array}$ \\
\hline 8 & $\begin{array}{l}\text { Japanese manufacturer of } \\
\text { tools } \\
\text { ( } 66 \text { employees })\end{array}$ & $\begin{array}{l}\text { Innovative tool for the effective } \\
\text { manufacturing of airplane panels }\end{array}$ & $\begin{array}{l}\text { New to the world, } \\
5 \text { months }\end{array}$ \\
\hline 9 & $\begin{array}{l}\text { Japanese manufacturer of } \\
\text { tools } \\
\text { ( } 240 \text { employees })\end{array}$ & $\begin{array}{l}\text { New machine to produce ceramic and } \\
\text { plastic components (used by } \\
\text { manufacturers of electronic devices, } \\
\text { e.g., mobile phones) }\end{array}$ & $\begin{array}{l}\text { Repositioning in the } \\
\text { market, } \\
36 \text { months }\end{array}$ \\
\hline 10 & $\begin{array}{l}\text { Japanese manufacturer of } \\
\text { electronic components } \\
\text { (8600 employees) }\end{array}$ & Super capacitor & $\begin{array}{l}\text { New product line, } \\
36 \text { months }\end{array}$ \\
\hline
\end{tabular}




\begin{tabular}{|c|c|c|c|}
\hline 11 & $\begin{array}{l}\text { Japanese manufacturer of } \\
\text { electrical products } \\
(10.000 \text { employees })\end{array}$ & eDRAM for PCs and digital cameras & $\begin{array}{l}\text { Product modification, } \\
24 \text { months }\end{array}$ \\
\hline 12 & $\begin{array}{l}\text { Japanese manufacturer of } \\
\text { electrical components and } \\
\text { products } \\
(10.000 \text { employees })\end{array}$ & $\begin{array}{l}\text { Laser machine for the semiconductor } \\
\text { industry (laser marker) }\end{array}$ & $\begin{array}{l}\text { Product modification, } \\
24 \text { month }\end{array}$ \\
\hline 13 & $\begin{array}{l}\text { Japanese manufacturer of } \\
\text { process equipment } \\
\text { (800 employees) }\end{array}$ & $\begin{array}{l}\text { Cleaning technology for LSI/FPD } \\
\text { manufacturing (water treatment } \\
\text { process) }\end{array}$ & $\begin{array}{l}\text { New to the world, } \\
24 \text { months }\end{array}$ \\
\hline 14 & $\begin{array}{l}\text { Japanese manufacturer of } \\
\text { electrical products } \\
\text { (10.000 employees) }\end{array}$ & $\begin{array}{l}\text { A new CVD technology, used to } \\
\text { replace chemical and/or mechanical } \\
\text { edging of DRAMS and circuit design }\end{array}$ & $\begin{array}{l}\text { Product modification, } \\
24 \text { months }\end{array}$ \\
\hline 15 & $\begin{array}{l}\text { German manufacturer of } \\
\text { electrical and electronic } \\
\text { components and products } \\
\text { ( } 200000 \text { employees) }\end{array}$ & $\begin{array}{l}\text { Sensor for measuring spark plug } \\
\text { temperature }\end{array}$ & $\begin{array}{l}\text { New to the world, } \\
12 \text { months }\end{array}$ \\
\hline 16 & $\begin{array}{l}\text { German automobile } \\
\text { manufacturer } \\
\text { (420000 employees) }\end{array}$ & $\begin{array}{l}\text { Low priced steering column (exchange } \\
\text { of component) }\end{array}$ & $\begin{array}{l}\text { Cost reduction, } \\
6 \text { months }\end{array}$ \\
\hline 17 & $\begin{array}{l}\text { German manufacturer of } \\
\text { pumps } \\
\text { ( } 25 \text { employees) }\end{array}$ & Special pumps for industrial purposes & $\begin{array}{l}\text { New to the world, } \\
6 \text { months }\end{array}$ \\
\hline 18 & $\begin{array}{l}\text { German manufacturer of } \\
\text { equipment for printing } \\
\text { machines } \\
\text { (160 employees) }\end{array}$ & Machine to dry printing ink & $\begin{array}{l}\text { New to the world, } \\
30 \text { months }\end{array}$ \\
\hline 19 & $\begin{array}{l}\text { German manufacturer of } \\
\text { pumps } \\
(125 \text { employees })\end{array}$ & Rotary pump & $\begin{array}{l}\text { Product modification, } \\
12 \text { months }\end{array}$ \\
\hline 20 & $\begin{array}{l}\text { German manufacturer of } \\
\text { hearing aids } \\
\text { ( } 70 \text { employees) }\end{array}$ & Hearing aid with rechargeable battery & $\begin{array}{l}\text { New product line, } \\
6 \text { months }\end{array}$ \\
\hline 21 & $\begin{array}{l}\text { German manufacturer of } \\
\text { installation equipment for } \\
\text { the shipping industry } \\
\text { (50 employees) }\end{array}$ & Headlights for the deck of a ship/ships & $\begin{array}{l}\text { New product line, } \\
42 \text { months }\end{array}$ \\
\hline 22 & $\begin{array}{l}\text { German manufacturer of } \\
\text { equipment for tyre } \\
\text { production } \\
\text { ( } 350 \text { employees) }\end{array}$ & Machine used for tyre production & $\begin{array}{l}\text { New product line, } \\
30 \text { months }\end{array}$ \\
\hline 23 & $\begin{array}{l}\text { German manufacturer of } \\
\text { apparatus for gas analysis } \\
\text { and level measuring } \\
\text { (174 employees) }\end{array}$ & $\begin{array}{l}\text { Apparatus for gas analysis with special } \\
\text { characteristics }\end{array}$ & $\begin{array}{l}\text { New to the world, } \\
24 \text { months }\end{array}$ \\
\hline
\end{tabular}




\begin{tabular}{|l|l|l|l|}
\hline $\mathbf{2 4}$ & $\begin{array}{l}\text { German engineering } \\
\text { company of equipment for } \\
\text { bulk handling } \\
\text { (75 employees) }\end{array}$ & Low priced metering roller & $\begin{array}{l}\text { Cost reduction, } \\
6 \text { months }\end{array}$ \\
\hline $\mathbf{2 5}$ & $\begin{array}{l}\text { German manufacturer of } \\
\text { ships and off-shore } \\
\text { equipment } \\
\text { (360 employees) }\end{array}$ & $\begin{array}{l}\text { Fire protection device for air } \\
\text { conditioning systems on ships }\end{array}$ & $\begin{array}{l}\text { New product line, } \\
18 \text { months }\end{array}$ \\
\hline $\mathbf{2 6}$ & $\begin{array}{l}\text { German manufacturer of } \\
\text { special drilling machines } \\
\text { (140 employees) }\end{array}$ & $\begin{array}{l}\text { Laser machine (first laser machine } \\
\text { developed in the firm) }\end{array}$ & $\begin{array}{l}\text { New product line, } \\
30 \text { months }\end{array}$ \\
\hline $\mathbf{2 7}$ & $\begin{array}{l}\text { German manufacturer of } \\
\text { medical technology } \\
\text { (11000 employees) }\end{array}$ & $\begin{array}{l}\text { Low priced high voltage generator for } \\
\text { X-ray equipment (exchange of } \\
\text { component) }\end{array}$ & $\begin{array}{l}\text { Cost reduction, } \\
24 \text { months }\end{array}$ \\
\hline $\mathbf{2 8}$ & $\begin{array}{l}\text { German manufacturer of } \\
\text { power machines and drives } \\
\text { (100 employees) }\end{array}$ & Electric drives for ships & $\begin{array}{l}\text { New product line, } \\
36 \text { months }\end{array}$ \\
\hline
\end{tabular}




\section{References}

[1] R. C. Cooper, E. J. Kleinschmidt: Screening new products for potential winners; Institute of Electrical and Electronics Engineers IEEE engineering management review Vol. 22 (1994) No. 4: pp. 24-30

[2] R. Verganti: Leveraging on systematic learning to manage the early phases of product innovation projects; R\&D Management Vol. 27 (1997) No. 4: pp. 377-392

[3] A. Khurana, S. R. Rosenthal: Integrating the fuzzy front end of new product development; Sloan Management Review Vol. 38 (1997) No. 2: pp. 103-120

[4] A. Khurana, S. R. Rosenthal: Towards holistic "front ends" in new product development; Journal of Product Innovation Management Vol. 15 (1998) No. 1: pp. $57-74$

[5] W. L. Moore, E. A. Pessemier: Product planning and management: designing and delivering value; McGraw-Hill, New York et al. 1993

[6] R. C. Cooper, E. J. Kleinschmidt: New products: The key factors in success; American Marketing Association, United States 1990

[7] X. M. Song, M. E. Parry: What separates Japanese new product winners from losers; Journal of Product Innovation Management Vol. 13 (1996) No. 5: pp. 422-439

[8] S. A. Murphy, V. Kumar: The front end of new product development: a Canadian survey; R\&D Management Vol. 27 (1997) No. 1: pp. 5-16

[9] R. K. Moenaert, A. De Meyer, W. E. Souder, D. Deschoolmeester: $\mathrm{R} \& \mathrm{D} /$ Marketing communication during the fuzzy front-end; IEEE Transactions on Engineering Management Vol. 42 (1995) No. 3: pp. 243-258

[10] J. W. Mullins, D. J. Sutherland: New product development in rapidly changing markets: an exploratory study; Journal of Product Innovation Management Vol. 15 (1998) No. 3: pp. 224-236

[11] J. Galbraith: Designing complex organizations; Addison-Wesley, Reading, Mass. 1973

[12] G. S. Lynn, A. E. Akgun: Innovation strategies under uncertainty: a contingency approach for new product development; Engineering Management Journal Vol. 10 (1998) No. 3: pp. 11-17

[13] R. Balachandra, J. H. Friar: Factors for success in R\&D projects and new product innovation: A contextual framework; IEEE Transactions on Engineering Management Vol. 44 (1997) No. 3: pp. 276-287 
[14] S. Mishra, D. Kim, D. H. Lee: Factors affecting new product success: crosscountry comparison; Journal of Product Innovation Management Vol. 13 (1996) No. 6: pp. 530-550

[15] X. M. Song, M. M. Montoya-Weiss: Critical development activities for really new versus incremental products; Journal of Product Innovation Management Vol. 15 (1998) No. 2: pp. 124-135

[16] T. M. Schlaak: Der Innovationsgrad als Schlüsselvariable: Perspektiven für das Management von Produktentwicklungen; Deutscher Universitäts-Verlag, Wiesbaden 1999

[17] R. W. Veryzer: Discontinuous innovation and the new product development process; Journal of Product Innovation Management Vol. 15 (1998) No. 4: pp. 304-321

[18] X. M. Song, M. Montoya-Weiss: The effect of perceived technological uncertainty on Japanese new product development; Academy of Management Journal Vol. 44 (2001) No. 1: pp. 61-80

[19] G. H. Hofstede: Culture's consequences, abridged edition; Sage, Newbury Park, London, New Delhi 1980

[20] X. M. Song, M. E. Parry: A cross- national comparative study on new product development processes: Japan and the United States; Journal of Marketing Vol. 61 (1997) No. 2: pp. 1-18

[21] U. Jürgens: Restructuring product development and production networks: introduction to the book; in: U. Jürgens (ed.): New product development and production networks: global industrial experience, pp. 1-19, Springer, Berlin, Heidelberg, New York 2000

[22] X. M. Song, J. Xie: The effect of R\&D-Manufacturing Marketing integration on new product performance in Japanese and U.S. firms: A contingency perspective; Marketing Science Institute, Working Paper Report No. 96-117, Cambridge Massachusetts November 1996

[23] W. E. Souder, X. M. Song: Analysis of U.S. and Japanese management processes associated with new product success and failure in high and low familiarity markets; Journal of Product Innovation Management Vol. 15 (1998) No. 3: pp. 208-223

[24] J.-H. Park: Vergleich des Innovationsmanagements deutscher, japanischer und koreanischer Unternehmen: Eine empirische Untersuchung am Beispiel der chemischen Industrie; Dissertation, Universität Mannheim 1996

[25] www.firmendatenbank.de

[26] H. Geschka: Creativity techniques in product planning and development: a view from West Germany; in: S. J. Parnes (ed.): Source book of creative problem-solving; Creative Education Foundation Press, Buffalo, New York 1992 
[27] L. Rochford: Generating and screening new product ideas; Industrial Marketing Management Vol. 20 (1991) No. 4: pp. 287-296

[28] N. R. Baker, S. G. Green, A. S. Bean: How management can influence the generation of ideas; Research Management Vol. 28 (1985) No. 6: pp. 35-42

[29] A. H. Rubinstein: At the front end of the R\&D/innovation process - idea development and entrepreneurship; International Journal of Technology Management Vol. 9 (1994) No. 5, 6, 7: pp. 652-677

[30] K. Förderer, K. Krey, K. Palme: Innovation und Mittelstand: eine Umfrage bei 1871 mittelständischen Unternehmen; Deutscher Instituts-Verlag, Köln 1998

[31] G. F. Smith: Idea generation techniques - a formulary of active ingredients; Journal of Creative Behavior Vol. 32 (1998) No. 2: pp. 107-134

[32] T. Sowrey: The generation of ideas for new products; Kogan Page, London 1987

[33] S. Harryson: Improving R\&D performance through networking - lessons from Canon and Sony; Arthur D. Little - Prism, Fourth Quarter 1996

[34] R. G. Cooper, E. J. Kleinschmidt: An investigation into the new product process - steps, deficiencies, and impact; Journal of Product Innovation Management Vol. 3 (1986) No. 3: pp. 71-85

[35] F. A. Johne, P. A. Snelson: Success factors in product innovation - a selective review of the literature; Journal of Product Innovation Management Vol. 5 (1988) No. 2: pp. 114-128

[36] B. Aggteleky, N. Bajina: Projektplanung: ein Handbuch für Führungskräfte; Hanser, München, Wien 1992

[37] L. Dwyer, R. Mellor: Organizational environment, new product process activities, and project outcomes; Journal of Product Innovation Management Vol. 8 (1991) No. 1: pp. 39-48

[38] E. Mansfield, S. Wagner: Organizational and strategic factors associated with probabilities of success in industrial R\&D; Journal of Business Vol. 48 (1975): pp. 179-198

[39] A. Balbontin, B. Yazdani, R. Cooper, W. E. Souder: New product development success factors in American and British firms; International Journal of Technology Management Vol. 17 (1999) No. 3: pp. 259-280

[40] M. A. Maidique, B. J. Zirger: A study of success and failure in product innovation; IEEE Transactions on Engineering Management Vol. EM-31 (1984) No. 4: pp. 192-203

[41] H. Albach, D. de Pay, R. Rojas: Quellen, Zeiten und Kosten von Innovationen - Deutsche Unternehmen im Vergleich zu ihren japanischen und 
amerikanischen Konkurrenten; Zeitschrift für Betriebswirtschaft ZfB Vol. 61 (1991) No. 3: pp. 311-325

[42] J. K. Pinto, D. P. Slevin: Critical success factors across the project life cycle; Project Management Journal Vol. 19 (1988): pp. 67-75

[43] C. Herstatt, C. Lüthje, B. Verworn: Die Gestaltung von Innovationsprozessen in kleinen und mittleren Unternehmen, in: J.-A. Meyer (ed.):

Innovationsmanagement in kleinen und mittleren Unternehmen: Jahrbuch der KMU-Forschung 2001; Vahlen, München 2001

[44] A. Webb: Project management for successful product innovation; Gower, Hampshire, Vermont 2000 